\title{
Universities protest against Australian spending cuts
}

Sydney. Australia's academic community is locked in a bitter conflict with the new conservative Coalition government over plans to cut operating grants to universities by up to 12 per cent, a reduction of up to $\mathrm{A} \$ 600$ million (US\$470 million).

The universities are complaining that the new government is breaking pre-election promises to sustain basic funding for higher education, and to add extra funds for infrastructure and postgraduate scholarships (see Nature 381, 5; 1996).

They now face the prospect of having to introduce fees for undergraduate courses and of raising the deferred graduate tax, a unique Australian scheme for repaying part of the costs of higher education.

Last week, 37 vice-chancellors met Amanda Vanstone, the minister who heads the Department of Employment, Education, Training and Youth Affairs (DEETYA), and learned that their earlier fears of a cut of up to 10 per cent were too cautious.

The Treasury and Finance Departments, which are leading the government's efforts to achieve budget cuts of \$A4 billion in both 1996 and 1997, want Vanstone's department to save about $\$ \mathrm{~A} 1.6$ billion this year.

Slashing the department's employment and training activities, despite an unemployment rate of nearly 9 per cent, has not achieved the necessary savings, and the higher education sector, which received $\mathrm{A} \$ 4.6$ billion a year in operating grants, has therefore been chosen for across-the-board reductions.

Universities use 30 per cent of these operating grants - supplemented by $\mathrm{A} \$ 400$ million from competitive grant schemes to finance their research activities, including the cost of infrastructure. They are upset by what they claim is an arbitrary approach to making cuts that appears to disregard longterm commitments and lacks any strategy from the new minister for higher education.

Vice-chancellors have united with staff, students and alumni in an unprecedented attack on the government. All universities are spelling out exactly what the effects of cuts will be. John Niland, vice-chancellor of the University of New South Wales, one of Australia's leading research universities, describes the cuts as hitting "like a cyclone", and says their impact would be "equivalent to closing down two of our largest faculties".

Another vice-chancellor claims that the cuts could lead to "a state of almost collapse". Results could include reduction in student numbers or increased student/staff ratios, as well as a freeze on a long-running claim by staff for increased salaries that now lag behind salaries in other countries.

They also warn that between 3,500 and
8,000 jobs could be lost, and that leading researchers may well choose to emigrate. The net effect would be to seriously damage Australia's reputation in Asia as an education and research provider earning around $\mathrm{A} \$ 2$ billion a year.

Publicity given to the vice-chancellors' protests has forced Vanstone into her first public statement on the issue. But the former lawyer only hinted that universities "would have some flexibility in how they make savings".

Universities created from colleges of education and technology institutes in the reforms introduced in 1987 by the then Labor government, as well as smaller universities in regional centres, are most worried about their capacity to cope with cuts. These universities have been keen to achieve the level of research funding enjoyed by the leading eight universities.

The vice-chancellors are demanding to see the Prime Minister, John Howard, and the Treasurer, Peter Costello, who are blaming the former (Labor) Finance Minister and now Opposition Leader, Kim Beazley, for the alleged 'black hole' of $A \$ 8$ billion in government funds.

Vanstone has become a focus of opposition attacks in the Senate, where the government lacks a majority and is threatened with the delay or rejection of legislation on partial privatization of the publicly owned telecommunications company and on the reduction of the power of trade unions.

Frank Hambly, the executive director of the Australian vice-chancellors' committee, describes the government's policies as "a real threat, after we really believed we had iron-clad [funding] guarantees". He says that universities may have to respond by cutting courses, closing some faculties, reducing the campuses in multi-campus institutions or amalgamating some universities.

Meanwhile, Peter McGauran, the Science and Technology Minister, has signalled his desire for greater selectivity in research and development by speaking out in favour of an expanded space programme. In particular, he has announced a plan to launch small communications satellites with Russian-built rockets from Darwin, in the Northern Territory, near the Equator.

Other areas designated for priority funding, such as marine science, are expected to follow, at the expense of some current priorities, such as astronomy. McGauran's rejection of Australia's bid to join the European Southern Observatory (see Nature 381, $100-101$; 1996) has generated widespread protests among astronomers. But so far their complaints have made little impact on the government.

\section{IMAGE UNAVAILABLE FOR COPYRIGHT REASONS}

Hands up: Gloria Steinem (left) is among the women supporting the global campaign.

\section{US coalition counters breast gene patents}

Washington. An international campaign to oppose the patenting of genes involved in susceptibility to breast cancer has been launched by Jeremy Rifkin, the long-time scourge of the US biotechnology industry. The campaign is being backed by a wide range of prominent women's rights activists and women's health and 'social justice' groups from both the developed and developing world.

In a statement due to be issued at a press conference in Washington this week, Rifkin describes efforts to patent and market commercially $B R C A 1$, the first such gene to be discovered, as representing an "assault on women" that "denies them control over the most intimate aspect of their being, their bodies' genetic blueprint".

The statement, which has been endorsed by, among others, the author Betty Friedan, Gloria Steinem, the consulting editor of $M s$. magazine, and Bella Abzug, co-chairperson of the Women's Environment and Development Organisation, also seeks support for legislation to protect genetic privacy and ensure non-discrimination by employers, insurance companies and others before the marketing of genetic screening tests.

Rifkin describes the campaign being launched this week as "the first genetic rights movement in history". He says that a worldwide coalition made up of more than 250 women's health and social justice groups plans to file a formal petition with the US Patent and Trademark Office challenging a patent application on the $B R C A 1$ gene and its mutations which has been filed by Myriad Genetics of Salt Lake City (see Nature 371, 271; 1994).

One of those who have endorsed Rifkin's statement is Vandana Shiva, president of the Research Foundation for Science, Technology and Natural Resource Policy in New Delhi, India. Shiva says that Indian women are worried that, once screening test results are available, "employers and insurance companies could be biased against women who have tested positive". 